\title{
Effectiveness of domestic rural wastewater treatment in soil-plant system
}

\author{
Maria Strzelczyk ${ }^{1}$, Aleksandra Steinhoff-Wrześniewska² \\ ${ }^{1}$ Institute of Technology and Life Sciences, Lower Silesian Research Centre in Wrocław; \\ ul. Zygmunta Berlinga 7, 51-209 Wrocław, Poland; e-mail: m.strzelczyk@itp.edu.pl; ORCID ID: 0000-0003-1252-0395 \\ ${ }^{2}$ Institute of Technology and Life Sciences, Lower Silesian Research Centre in Wrocław; \\ ul.Zygmunta Berlinga 7, 51-209 Wrocław, Poland; e-mail: aleksandra.sw@gmail.com; ORCID ID: 0000-0002-5771-5731
}

(C) 2019 Authors. This is an open access publication, which can be used, distributed and reproduced in any medium according to the Creative Commons CC-BY 4.0 License requiring that the original work has been properly cited.

Received: 23 August 2019; accepted: 7 November 2019; first published online: 16 December 2019

\begin{abstract}
The characteristics of Polish rural agglomerations indicate that only $32 \%$ of these areas are villages typified by compact buildings where the use of a collective sewage system is economically justified. In other areas, it is necessary to apply solutions that allow for the sewage utilization in place of their creation and safe discharge into the environment, e.g. in the form of home systems based on biological processes, e.g. in soil-plant systems. The purpose of the work was to determine the soil-plant efficiency of wastewater treatment with the use of so-called energy plants. The experiment was conducted in 2012-2014 in lysimeters at a depth of $130 \mathrm{~cm}$ and $100 \mathrm{~cm}$ in diameter. These were submerged in the ground, filled with sand clay and equipped with installations enabling the drainage of gravity water in the form of lysimeter effluents. Two species of plants were used: Miscanthu giganteus and Sida hermaphrodita (L.) Rusby. They were irrigated with pre-treated domestic sewage (variant I - $1200 \mathrm{~mm} \cdot$ year $^{-1}$ and variant II $-1600 \mathrm{~mm} \cdot$ year $\left.^{-1}\right)$. For irrigation, sewage from a group of buildings inhabited by six families was used. Raw domestic sewage was discharged into the tank, consisting of four chambers, which constituted a relatively good level of pre-cleaning. For the irrigation of plants in the experiment, pre-treated sewage was used. In order to determine the effectiveness of wastewater treatment in the soil-plant environment, the concentrations of the following components were determined in the effluents: TSS, $\mathrm{BOD}_{5}, \mathrm{COD}, \mathrm{N}_{\text {tot }}$. The quantities of pollutants contained in the sewage were characterized by considerable variability, especially in relation to COD (390.6$1583.0 \mathrm{mg} \mathrm{O}_{2} \cdot \mathrm{dm}^{-3}$ ) and $\mathrm{N}_{\text {tot }}\left(47.0-250.2 \mathrm{mg} \mathrm{N} \cdot \mathrm{dm}^{-3}\right)$.
\end{abstract}

Keywords: waste water treatment plant, lysimeter leachates, soil-plant wastewater, energy plant

\section{INTRODUCTION}

In Poland, about $73.5 \%$ of its society uses wastewater treatment plants. In cities, the percentage is on average $94.8 \%$ but in rural areas only $41 \%$. The problem of access to sewage treatment plants in rural areas varies according to region. The following voivodships have the highest percentage of the rural population using sewage treatment plants: Pomorskie (62.1\%), Zachodniopomorskie (57.1\%) and Podkarpackie (57.1\%). The worst situations are in following voivodships: Podlaskie (22.8\%),
Łódzkie (25.5\%), Lubelskie (24.8\%) and Mazowieckie (30.0\%) (GUS 2017). Although in the years 2000-2016 there was a significant increase in the use of sewage treatment plants by the rural population, from $10.8 \%$ to almost $40 \%$, the problem of rural wastewater treatment is still significant. However, the development of a collective sewage system is not the right solution for all rural areas. According to the Opinion of the European Economic and Social Committee on the facts and prospects of relevant environmental technologies in the accession countries the length of the sewage channel per inhabitant 
should be from 0.5 to $2.0 \mathrm{~m}$, and in rural areas this can range from 5 to $10 \mathrm{~m}$. The average number of family people members in rural areas is 3.4 people (GUS 2012). The characteristics of Polish rural agglomerations indicate that only $32 \%$ of these areas are villages typified by compact buildings for distances between farms $\leq 45 \mathrm{~m}$. The remaining areas are characterized by dispersed and intermediate buildings (Eymontt \& Gutry 2010), where the use of a collective sewage system is too expensive. This situation forces the adoption of solutions which allow the disposal of sewage where tit is created and ensures its safe discharge into the environment e.g. in the form of household systems based on biological processes, such as soil-plant systems. So far, these systems have most commonly used plants such as grass, trees or reeds (Strzelczyk et al. 2012). Soil-plant treatment plants are characterized by long-term stability and the much higher efficiency of wastewater treatment than the ground-reed deposit. In order to increase this efficiency, the rules proper operation of the treatment plant should be observed (Czyżyk et al. 2012).

The purpose of the work was to determine the soil-plant efficiency of wastewater treatment with the use of so-called energy plants characterized by rapid growth and the high demand for water and nutrients associated with it.

\section{METHODS}

The experiment was conducted between 2012-2014 in lysimeters filled with slightly loamy soil, containing $13 \%$ of earthy fraction parts $(<0.02 \mathrm{~mm})$, $24.8 \%$ of dust parts $(0.02-0.1 \mathrm{~mm})$ and $62.2 \%$ of sand $(0.1-1.0 \mathrm{~mm})$. The lysimeters were filled with soil in such a way as to reliably reproduce the natural soil profile, preserving individual layers. Lysimeters, with a diameter of $100 \mathrm{~cm}$ and $130 \mathrm{~cm}$ deep, were completely submerged in the ground. In the bottom of the lysimeters special installation that allows drainage of gravity water in the form of lysimeter leachates was installed. Lysimets were sown by Miscanthus $x$ Giganteus (Miscanthus) and Sida hermaphrodita (L.) Rusby, known by the common names Virginia fanpetals and Virginia mallow (mallow). The research covered sewage from a sewage treatment plant with an RLM of up to 2000. For irrigation sewage from a group of buildings inhabited by six families was used. The wastewater from the building complex was discharged into a reservoir consisting of four chambers. For the irrigation of plants, pre-treated sewage was used (from the $4^{\text {th }}$, last chamber). In the experiment, two variants of irrigation, were used (variant I - $1200 \mathrm{~mm}$ sewage.year ${ }^{-1}$ and variant II - $1600 \mathrm{~mm}$ sewage.year ${ }^{-1}$ ). In the experiment, a soil-plant system of household sewage treatment was applied. The hydraulic characteristics of this solution are different than in ground-plant or constructed wetlands (WCs). In the soil and plant system, significantly lower hydraulic loads are used due to the higher risk of the contamination of groundwater, especially on more permeable soils. Irrigation doses were established based on many years of research conducted on the irrigation fields of Wrocław, Kluczbork, and Legnica, which show that an annual dose of $2000 \mathrm{~mm}$ sewage should not be exceeded, especially on permeable soils (Czyżyk 1994). Annual wastewater doses were carried out in single doses of $150 \mathrm{~mm}$ at regular intervals (for combination - $1200 \mathrm{~mm}$ of one and a half month; for combination - $1600 \mathrm{~mm}$ - every month). All variants of the experiment were carried out in three replicates. Samples of wastewater used in the experiment and leachates from lysimeters were subjected to physicochemical tests. In order to determine the effectiveness of wastewater treatment in the soil-plant environment, both in wastewater used for irrigation and in leachate from lysimeters, pollutant indicators were determined in accordance with the requirements of the applicable law (Rozporządzenie 2014).

To determine the size of the pollution indicators in lysimeter leachates and sewage, the following methods were used: TSS (total suspended solids) by the gravimetric method, $\mathrm{BOD}_{5}$ by the dilution method, COD by the dichromate method, nitrogen and its forms $\left(\mathrm{N}_{\text {tot }}\right)$ using the indophenol colorimetric method, total phosphorus (P) by the colorimetric method using ammonium molybdate and sodium pyrosulphite. All methods used are standardized.

\section{RESULTS AND DISCUSSION}

The wastewater dose used in the experiment is not high in comparison with the literature data. Pawęs$\mathrm{ka}$, analyzing the operation of the existing soilplant treatment plant in Brzeźno, states that the 
annual sewage rates range from 2000 to $5500 \mathrm{~mm}$, but the plants that cover the surface of the treatment plant were trees (poplars) that have a higher water demand than mallow and Sida (Pawęska \& Kuczewski 2016). The quantity of impurities contained in the wastewater has significant volatility. The amount of suspended solids found in the wastewater used in the experiment ranged 110$581 \mathrm{mg} \cdot \mathrm{dm}^{-3}$ whereas their average amount in lysimeter leachates did not exceed $70 \mathrm{mg} \cdot \mathrm{dm}^{-3}$.
The value of COD in the wastewater varied significantly (Tab. 1). The $\mathrm{BOD}_{5}, \mathrm{COD}$ and TSS wastewater used in experience have average concentration of pollution according to a wastewater treatment plant with RLM of up to 2000. The values provided by Miernik (2007) regarding the chemical indicators of wastewater from the rural wastewater treatment plant are higher (in the range: TSS $118-1876 \mathrm{mg} \cdot \mathrm{dm}^{-3}$, BOD $_{5} 230-980 \mathrm{mg} \mathrm{O} \cdot \mathrm{dm}^{-3}$, COD 380-2847 $\mathrm{mg} \mathrm{O}_{2} \cdot \mathrm{dm}^{-3}$ ).

Table 1

Minimum, maximum and average values of pollution indicators contained in lysimeter effluents and sewage $\frac{\min -\mathrm{max}}{\text { average }(S D)}\left[\mathrm{mg} \cdot d m^{-3}\right]$ in 2012-2014

\begin{tabular}{|c|c|c|c|c|c|c|}
\hline $\begin{array}{l}\text { Pollution } \\
\text { indicator }\end{array}$ & Year & $\begin{array}{c}\text { Sida hermaphro- } \\
\text { dita (L.) Rusby } \\
\text { Variant II** }\end{array}$ & $\begin{array}{c}\text { Sida hermaphro- } \\
\text { dita }(\mathrm{L} .) \text { Rusby } \\
\text { Variant } \mathrm{I}^{*}\end{array}$ & $\begin{array}{c}\text { Miscanthus } x \\
\text { giganteus } \\
\text { Variant } I^{\star}\end{array}$ & $\begin{array}{c}\text { Miscanthus } x \\
\text { giganteus } \\
\text { Variant II }\end{array}$ & Wastewater \\
\hline \multirow{6}{*}{$\begin{array}{l}\text { TSS } \\
{\left[\mathrm{mg} \text { TSS } \cdot \mathrm{dm}^{-3}\right]}\end{array}$} & \multirow{2}{*}{2012} & $21.0-85.0$ & $\underline{34.0-118.0}$ & $\underline{47.0-82.0}$ & $\underline{37.0-79.0}$ & $206.0-403.0$ \\
\hline & & $\overline{59.9(17.7)}$ & $\overline{68.5(26.2)}$ & $\overline{62.0(11.6)}$ & $\overline{59.9(14.2)}$ & $\overline{295.9(63.7)}$ \\
\hline & \multirow{2}{*}{2013} & $30.0-83.0$ & $23.0-71.0$ & $15.0-98.0$ & $15.0-110.0$ & $\underline{120.0-581.0}$ \\
\hline & & $\overline{63.0(18.2)}$ & $\overline{45.0(22.2)}$ & $\overline{50.0(32.1)}$ & $\overline{61.0(28.6)}$ & $\overline{284.0(133.0)}$ \\
\hline & \multirow{2}{*}{2014} & $21.0-94.0$ & $26.0-90.0$ & $24.0-83.0$ & $32.0-104.0$ & $110.0-323.0$ \\
\hline & & $\overline{55.0(28.8)}$ & $\overline{48.0(25.3)}$ & $\overline{53.0(21.5)}$ & $67.0(19.0)$ & $\overline{250.0(52.4)}$ \\
\hline \multirow{6}{*}{$\begin{array}{l}\mathrm{BOD}_{5} \\
{\left[\mathrm{mg} \mathrm{O}_{2} \cdot \mathrm{dm}^{-3}\right]}\end{array}$} & \multirow{2}{*}{2012} & $4.0-69.0$ & $10.0-62.0$ & $8.0-25.0$ & $4.0-67.0$ & $210.0-680.0$ \\
\hline & & $22.8(19.6)$ & $\overline{32.4(16.2)}$ & $\overline{16.2(6.5)}$ & $\overline{15.2(21.0)}$ & $\overline{396.4(160.9)}$ \\
\hline & \multirow{2}{*}{2013} & $16.0-40.0$ & $22.0-56.0$ & $8.0-30.0$ & $6.7-14.0$ & $170.0-530.0$ \\
\hline & & $\overline{25.0(8.0)}$ & $\overline{32.8(10.9)}$ & $\overline{17.7(7.7)}$ & $\overline{8.6(2.5)}$ & $\overline{329.2(108.7)}$ \\
\hline & \multirow{2}{*}{2014} & $13.0-58.0$ & $\underline{18.0-39.0}$ & $3.0-30.0$ & $7.0-29.0$ & $\underline{290.0-630.0}$ \\
\hline & & $\overline{23.5(12.8)}$ & $\overline{26.7(7.0)}$ & $\overline{12.6(9.3)}$ & $\overline{15.1(6.2)}$ & $\overline{427.7(89.1)}$ \\
\hline \multirow{6}{*}{$\begin{array}{l}\mathrm{COD} \\
{\left[\mathrm{mg} \mathrm{O}_{2} \cdot \mathrm{dm}^{-3}\right]}\end{array}$} & \multirow{2}{*}{2012} & $\underline{83.3-149.8}$ & $70.3-231.5$ & $67.4-162.5$ & $59.0-114.6$ & $390.6-1172.0$ \\
\hline & & $100.8(24.7)$ & $\overline{120.0(56.0)}$ & $\overline{91.8(34.5)}$ & $\overline{80.6(18.4)}$ & $\overline{738.1(233.3)}$ \\
\hline & \multirow{2}{*}{2013} & $72.2-146.2$ & $99.6-205.5$ & $71.7-154.0$ & $55.0-134.4$ & $577.0-1583.0$ \\
\hline & & $\overline{107.8(31.7)}$ & $\overline{140.9(45.9)}$ & $\overline{110.9(37.3)}$ & $\overline{101.4(36.0)}$ & $\overline{850.0(264.6)}$ \\
\hline & \multirow{2}{*}{2014} & $95.2-167.3$ & $89.5-150.8$ & $62.4-182.5$ & $71.4-200.0$ & $597.6-1200.0$ \\
\hline & & $\overline{137.5(46.7)}$ & $\overline{108.0(22.3)}$ & $\overline{101.8(49.4)}$ & $\overline{127.4(46.7)}$ & $\overline{880.0(162.7)}$ \\
\hline \multirow{6}{*}{$\begin{array}{l}\mathrm{N}_{\text {tot }} \\
{\left[\mathrm{mg} \mathrm{N} \cdot \mathrm{dm}^{-3}\right]}\end{array}$} & \multirow{2}{*}{2012} & $56.5-127.2$ & $53.1-115.9$ & $40.7-108.6$ & $39.5-97.5$ & $61.9-262.6$ \\
\hline & & $\overline{84.1(25.4)}$ & $\overline{83.7(19.3)}$ & $\overline{70.2(23.4)}$ & $\overline{74.8(19.1)}$ & $\overline{102.7(49.6)}$ \\
\hline & \multirow{2}{*}{2013} & $11.6-87.0$ & $17.4-174.5$ & $8.8-93.0$ & $7.2-64.6$ & $47.0-164.2$ \\
\hline & & $\overline{50.4(29.2)}$ & $\overline{55.4(56.0)}$ & $\overline{37.2(36.9)}$ & $\overline{29.3(22.0)}$ & $\overline{102.6(38.1)}$ \\
\hline & \multirow{2}{*}{2014} & $16.5-97.4$ & $25.1-86.0$ & $8.5-65.9$ & $15.0-35.7$ & $98.9-250.2$ \\
\hline & & $\overline{65.3(32.7)}$ & $53.6(24.0)$ & $27.7(15.6)$ & $27.6(10.5)$ & $144.3(36.5)$ \\
\hline \multirow{6}{*}{$\begin{array}{l}\mathrm{P} \\
{\left[\mathrm{mg} \mathrm{P} \cdot \mathrm{dm}^{-3}\right]}\end{array}$} & \multirow{2}{*}{2012} & $0.7-1.2$ & $0.7-0.9$ & $0.7-1.1$ & $0.7-1.1$ & $7.0-13.9$ \\
\hline & & $0.9(0.22)$ & $\overline{0.8(0.08)}$ & $\overline{0.9(0.13)}$ & $\overline{0.9(0.14)}$ & $\overline{10.2(2.49)}$ \\
\hline & \multirow{2}{*}{2013} & $0.6-1.2$ & $0.7-1.1$ & $0.7-1.0$ & $0.8-1.1$ & $7.1-14.2$ \\
\hline & & $\overline{0.9(0.22)}$ & $\overline{0.9(0.14)}$ & $\overline{0.9(0.13)}$ & $\overline{0.9(0.11)}$ & $\overline{10.2(2.89)}$ \\
\hline & \multirow{2}{*}{2014} & $0.8-1.5$ & $0.7-1.3$ & $0.7-1.2$ & $0.8-1.4$ & $10.5-14.0$ \\
\hline & & $\overline{1.3(0.23)}$ & $\overline{1.1(0.20)}$ & $\overline{1.1(0.18)}$ & $\overline{1.2(0.19)}$ & $\overline{13.2(1.25)}$ \\
\hline
\end{tabular}

* average values for 8 results,

** average values for 12 results. 
In relation to the majority of the analyzed indicators, there were no significant differences between the individual variants of the experiment. In most cases, the values of these indicators were higher in variants with a larger annual dose of wastewater. Particularly noteworthy is the total amount of nitrogen $\left(\mathrm{N}_{\mathrm{tot}}\right)$ in individual variants. In the first year of research (2012), there were no significant differences in its concentration in individual variants in subsequent years. There were differences between variants where the plant used was Sida hermaphrodita (L.) Rusby and variants with Mischanthus x giganteus.

The values of the indicators show a higher nitrogen uptake on combinations where Mischanthus was planted. This might be related to the growing demand for this component in subsequent years, when tested plants reach full yields, a stage which is associated with a significant uptake of nutrients.

The effectiveness of wastewater treatment in the soil and plant environment is demonstrated by the reduction of pollution. It is calculated on the basis of the content of these pollutants contained in the wastewater used in the experiment and their content in the effluents from the lysimeters. The threeyear studies showed the high efficiency of the sewage treatment technology applied (Figs. 1-5). The average annual reduction in the amount of total suspended solids did not show differences between the variants. The average percentage of reduction for the analyzed period ranged from 80 to $83 \%$ (Fig. 1). Also, in relation to the reduction of organic pollutants expressed in $\mathrm{BOD}_{5}$, very good cleaning results were achieved. In variants with an annual wastewater dose of $1200 \mathrm{~mm}$, the average annual percentage reduction in this ratio reached $90 \%$ in the case of mallow (Sida) and $92 \%$ in the variant with Miscanthus at a dose of $1600 \mathrm{~mm}, 87$ and $89 \%$, respectively. The average reduction values of this indicator (in 2012-2014) in individual months are shown in Figure 2. Concentrations of pollutants expressed in $\mathrm{BOD}_{5}$ in lysimeter effluents were lower than the admissible values found in the Annex to the Regulation of the Minister of the Environment of November 18, 2014 (Rozporządzenie 2014) which is $25 \mathrm{mg} \mathrm{O}_{2} \cdot \mathrm{dm}^{-3}$.

In variants with an annual wastewater dose of $1200 \mathrm{~mm}$, the average annual percentage reduction reached $87 \%$ in the case of Sida and $89 \%$ in the variant with Miscanthus, and at a dose of $1600 \mathrm{~mm}$ in case of Sida - 90\% and in case of Miscanthus - $91 \%$. The concentration of total nitrogen in the effluents from lysimeters planted with Miscanthus was lower than in the effluents from lysimeters in which mallow was grown.

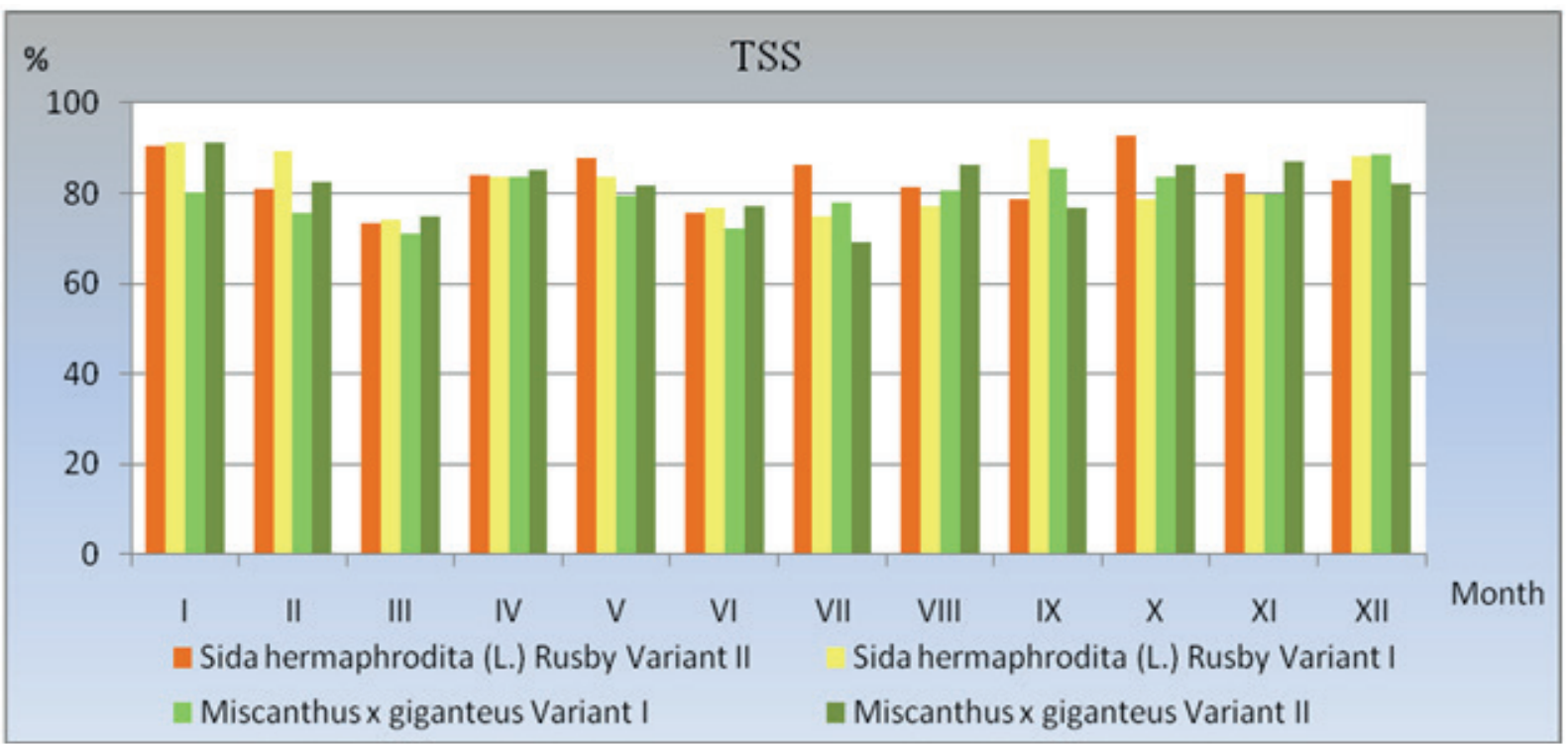

Fig. 1. The average percentage of reduction in the amount of TSS in 2012-2014 


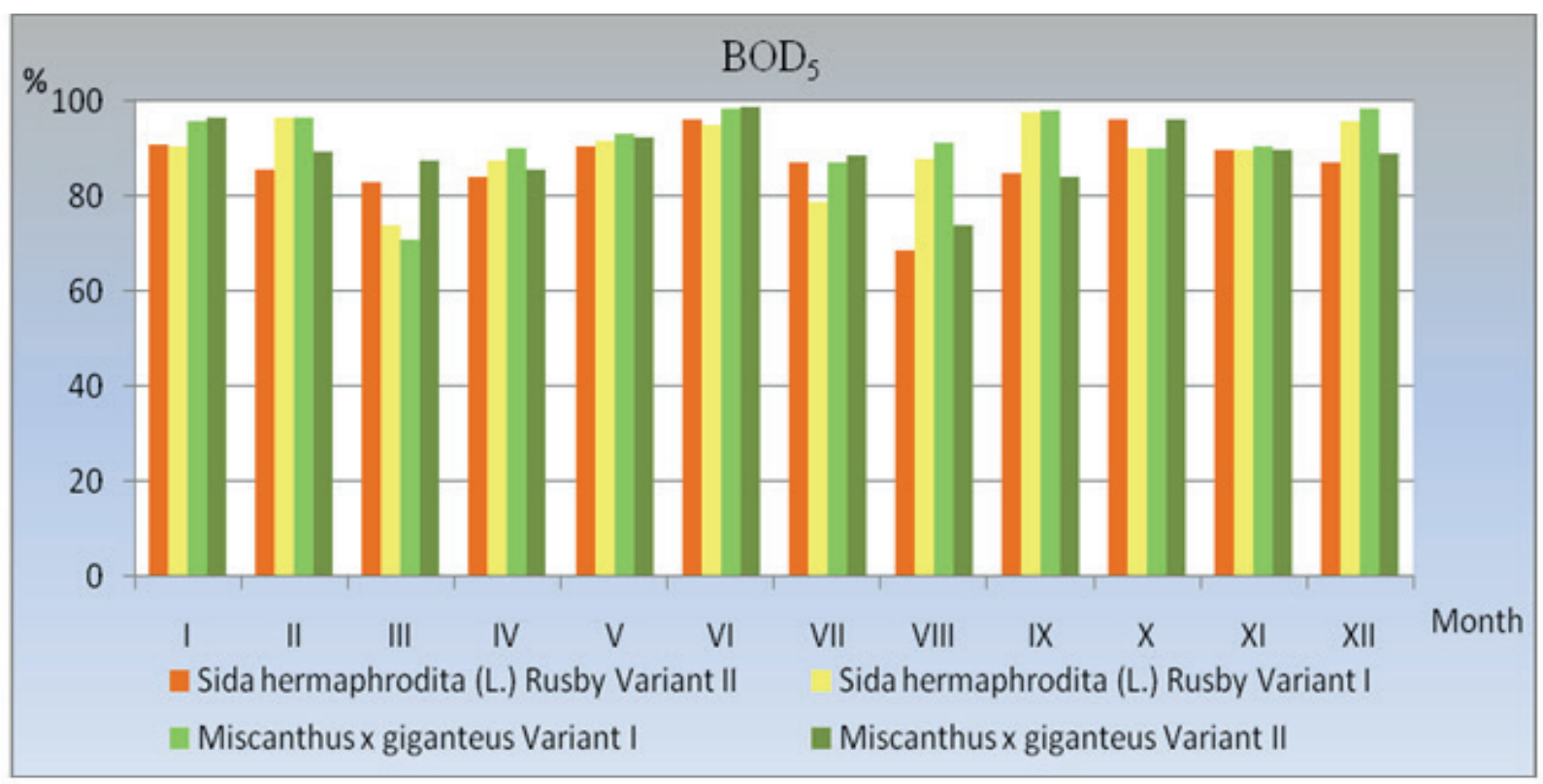

Fig. 2 The average percentage of reduction in the amount of $B_{5} D_{5}$ in 2012-2014

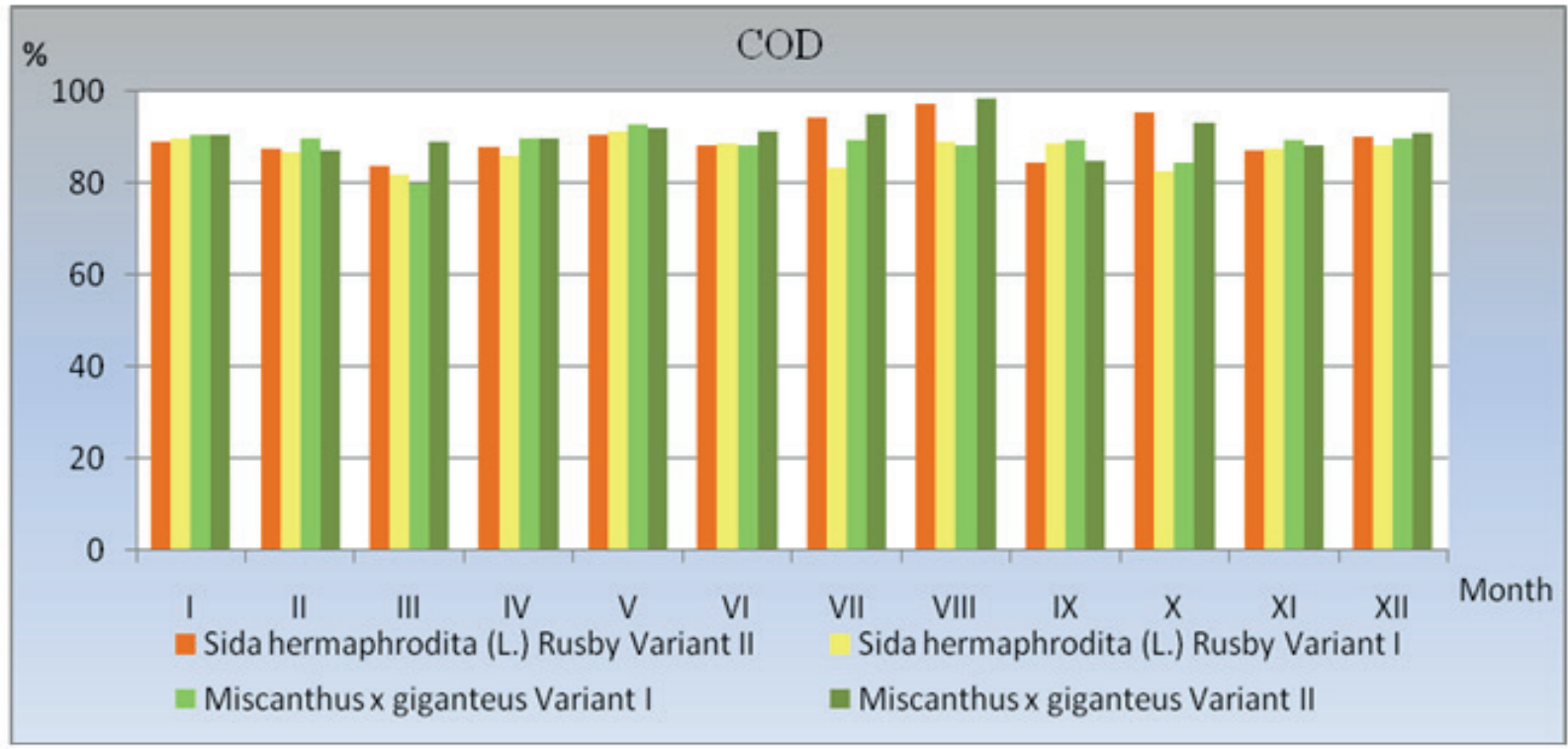

Fig. 3. The average percentage of reduction in the amount of COD in 2012-2014

The reduction of pollution in individual months varied but the advantage of the variants with Miscanthus is noticeable. The influence of the size of the annual irrigation dose used on the obtained wastewater treatment effects is also clearly marked. The average annual percent reduction in $\mathrm{N}_{\text {tot }}$ in variants with an annual dose of $1200 \mathrm{~mm}$ sewage amounted to $48 \%$ in the case of mallow and $63 \%$ in the variant with Miscanthus and at a dose of $1600 \mathrm{~mm}$, respectively 46 and $53 \%$. In the analysis of the obtained results reduction of the value of the nitrogen reduction indicator (increase its concentration in lysimeter leachate) during the growing season what was surprising.

However, it should be emphasized that during this period leachates were less frequent than in the non-vegetative period and occurred only in periods of high precipitation and their amounts were 
definitely lower. In connection with the above, the nitrogen load leached from the lysimeter was small, despite the relatively high concentrations of this element in the discharged water. The last analyzed indicator of impurities was general phosphorus.

The concentration of this element in the waters draining from the lysimeters was not markedly fluctuated and ranged from $0.6-1.5 \mathrm{mg} \mathrm{P} \cdot \mathrm{dm}^{-3}$. The average efficiency of phosphorus removal from wastewater in the studied soil and plant system in variant I was $83 \%$ for Sida and $85 \%$ for Miscanthus and in variant II $76 \%$ and $77 \%$ respectively. In the case of this element, differences at level $7-8 \%$ in the effects achieved in dependence on the amount of the hydration dose were found. There was also a slight decrease in the effectiveness of the removal of this element in subsequent years of research in all variants of the experiment. Average percentage of reduction in the amount of pollution indicators and standard deviations from particular years are shown in Table 2.

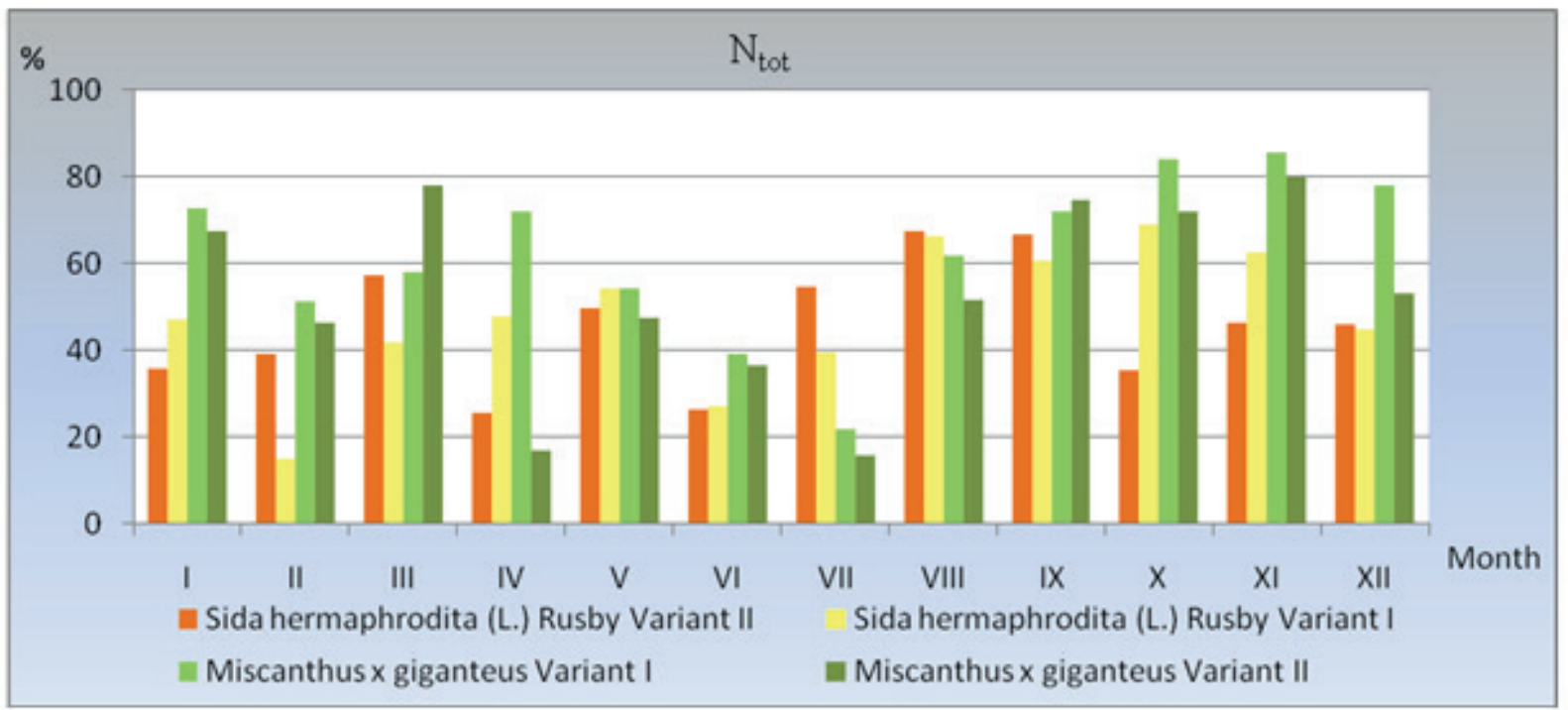

Fig. 4. The average percentage reduction in the amount of $N_{\text {tot }}$ in 2012-2014

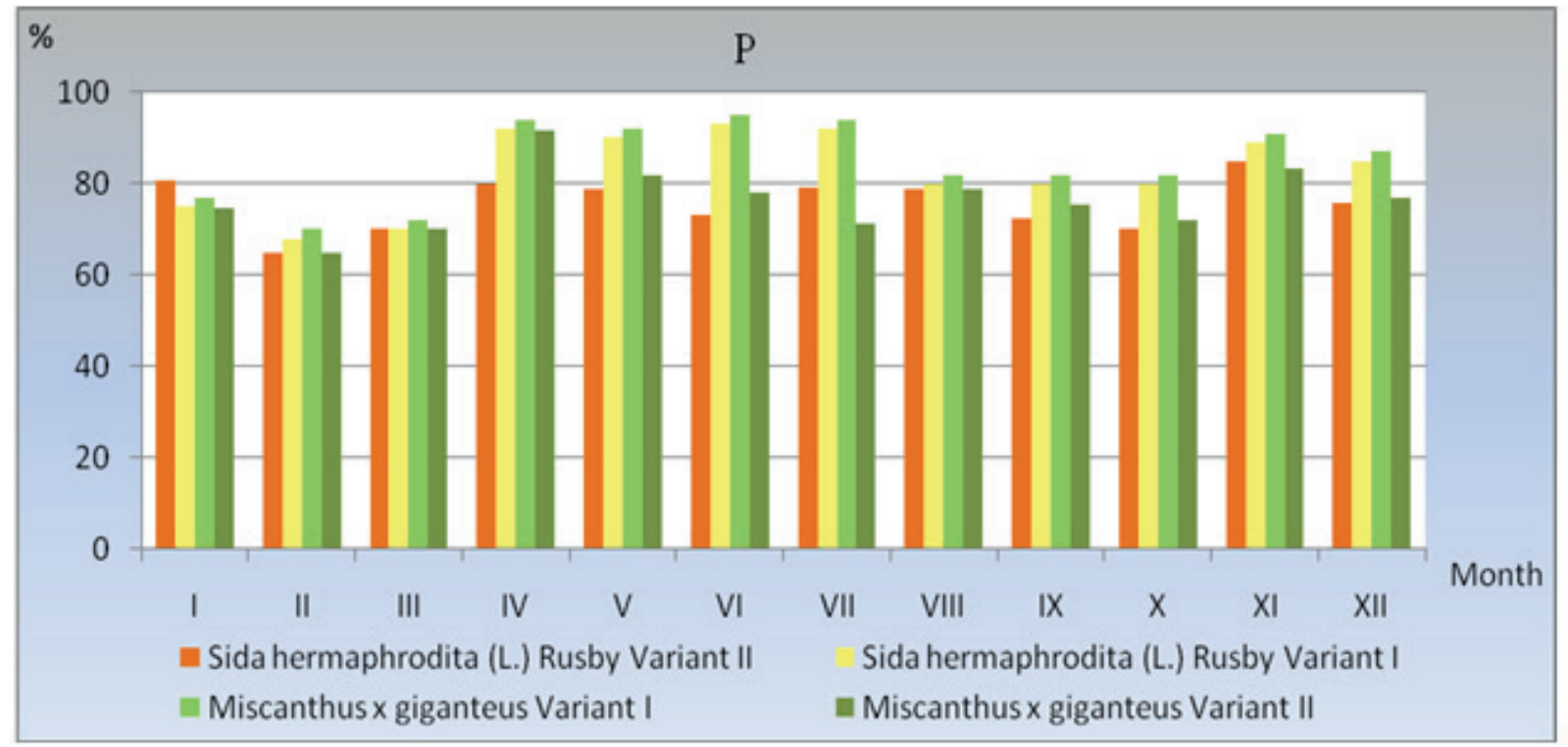

Fig. 5. The average percentage of reduction in the amount of $P$ in 2012-2014 
Table 2

Average percentage reduction in the amount of pollution indicators and standard deviations in particular years $\frac{\text { average }}{S D}$

\begin{tabular}{|c|c|c|c|c|c|}
\hline $\begin{array}{l}\text { Pollution } \\
\text { indicator }\end{array}$ & Year & $\begin{array}{c}\text { Sida hermaphrodi- } \\
\text { ta }(\mathrm{L} .) \text { Rusby } \\
\text { Variant II }\end{array}$ & $\begin{array}{c}\text { Sida hermaphrodi- } \\
\text { ta (L.) Rusby } \\
\text { Variant I }{ }^{*}\end{array}$ & $\begin{array}{c}\text { Miscanthus } \\
x \text { giganteus } \\
\text { Variant } \mathrm{I}^{\star}\end{array}$ & $\begin{array}{c}\text { Miscanthus } \\
x \text { giganteus } \\
\text { Variant } \mathrm{II}^{\star *}\end{array}$ \\
\hline \multirow{6}{*}{$\begin{array}{l}\text { TSS } \\
{\left[\mathrm{mg} \text { TSS } \cdot \mathrm{dm}^{-3}\right]}\end{array}$} & \multirow{2}{*}{2012} & 76 & 77 & 79 & 76 \\
\hline & & $\overline{6.4}$ & $\overline{4.5}$ & $\overline{4.7}$ & $\overline{3.5}$ \\
\hline & \multirow{2}{*}{2013} & 93 & 92 & 91 & 91 \\
\hline & & $\overline{4.9}$ & $\overline{2.2}$ & $\overline{4.2}$ & $\overline{5.9}$ \\
\hline & \multirow{2}{*}{2014} & 80 & 79 & 74 & 75 \\
\hline & & $\overline{8.0}$ & $\overline{11.0}$ & $\overline{5.3}$ & $\overline{19.1}$ \\
\hline \multirow{6}{*}{$\begin{array}{l}\mathrm{BOD}_{5} \\
{\left[\mathrm{mg} \mathrm{O}_{2} \cdot \mathrm{dm}^{-3}\right]}\end{array}$} & \multirow{2}{*}{2012} & 76 & 77 & 79 & 76 \\
\hline & & $\overline{6.4}$ & $\overline{4.5}$ & $\overline{4.7}$ & $\overline{3.5}$ \\
\hline & \multirow{2}{*}{2013} & 95 & 97 & 99 & 97 \\
\hline & & $\overline{3.6}$ & $\overline{2.8}$ & $\overline{0.5}$ & $\overline{1.8}$ \\
\hline & \multirow{2}{*}{2014} & 93 & 94 & 96 & 97 \\
\hline & & $\overline{2.3}$ & $\overline{2.9}$ & $\overline{1.9}$ & $\overline{2.2}$ \\
\hline \multirow{6}{*}{$\begin{array}{l}\mathrm{COD} \\
{\left[\mathrm{mg} \mathrm{O}_{2} \cdot \mathrm{dm}^{-3}\right]}\end{array}$} & \multirow{2}{*}{2012} & 87 & 83 & 87 & 89 \\
\hline & & $\overline{6.1}$ & $\overline{4.9}$ & $\overline{4.3}$ & $\overline{6.4}$ \\
\hline & \multirow{2}{*}{2013} & 93 & 95 & 95 & 94 \\
\hline & & $\overline{3.9}$ & $\overline{1.3}$ & $\overline{1.2}$ & $\overline{3.7}$ \\
\hline & \multirow{2}{*}{2014} & 88 & 85 & 86 & 89 \\
\hline & & $\overline{3.5}$ & $\overline{4.2}$ & $\overline{5.1}$ & $\overline{4.1}$ \\
\hline \multirow{6}{*}{ 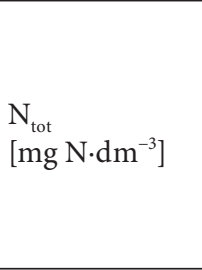 } & \multirow{2}{*}{2012} & 36 & 43 & 36 & 31 \\
\hline & & $\overline{20.8}$ & $\overline{20.6}$ & $\overline{19.2}$ & $\overline{20.1}$ \\
\hline & \multirow{2}{*}{2013} & 58 & 42 & 58 & 66 \\
\hline & & $\overline{20.3}$ & $\overline{26.8}$ & $\overline{31.1}$ & $\overline{25.7}$ \\
\hline & \multirow{2}{*}{2014} & 55 & 58 & 79 & 81 \\
\hline & & $\overline{21.7}$ & $\overline{19.1}$ & $\overline{17.2}$ & $\overline{8.0}$ \\
\hline \multirow{6}{*}{ 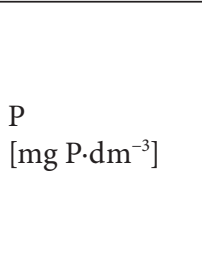 } & \multirow{2}{*}{2012} & 88 & 73 & 71 & 90 \\
\hline & & $\overline{4.6}$ & $\overline{12.7}$ & $\overline{9.8}$ & $\overline{3.3}$ \\
\hline & \multirow{2}{*}{2013} & 83 & 68 & 67 & 80 \\
\hline & & $\overline{10.6}$ & $\overline{61.0}$ & $\overline{13.7}$ & $\overline{10.9}$ \\
\hline & \multirow{2}{*}{2014} & 64 & 58 & 61 & 65 \\
\hline & & $\overline{10.2}$ & $\overline{9.3}$ & $\overline{6.8}$ & $\overline{8.3}$ \\
\hline
\end{tabular}

* average values for 8 results,

** average values for 12 results.

A much smaller reduction was observed by Vymazal (2002) in the case of phosphorus (26.795.0\%) and nitrogen (24.5-59.0\%). On the other hand, Pawęska \& Malczewska (2009) found a different situation on the ground and plant sewage treatment facilities. On the three objects analyzed by them, the percentage of the reduction of phosphorus was very high (86.4-98.6\%), while in the case of total nitrogen ( $57.0 \%$ to almost $100.0 \%$ ). In light of these data, the results of our own research appear correct and correspond to the values obtained from other sites in Poland (Pawęska
\& Malczewska 2009). There are many different solutions based on the use of biological processes in the soil-plant or primer-plant system (Paluch et al. 2006, Soroko 2006). The effectiveness of wastewater treatment in this type of solution is often characterized by seasonal variability (Krzanowski 2005, Eymontt \& Rogulski 2006, Jucherski 2007, Gutry et al. 2009, Czyżyk et al. 2012).

The method of household wastewater treatment presented in the article can be introduced in households not only in the countryside but also in agglomerations, among the peripheral areas with 
an absence of sewerage provision. The Regulation of the Minister of the Environment of November 18, 2014 (Rozporzadzenie 2014) specifies the conditions to be met when introducing sewage into waters or into the ground, and on substances particularly harmful to the aquatic environment in Annexes 2 and 3. It sets different requirements regarding the effectiveness of wastewater treatment depending on the location of the treatment plant (in the agglomeration or outside it). The research covered sewage from sewage treatment plant with RLM up to 2000. The research shows that average annual reductions of pollution indicators meet the requirements set out in Annexes 2 and 3 of the Regulation with reference to $\mathrm{BOD}_{5} \mathrm{COD}$ and $\mathrm{P}$ (Rozporządzenie 2014). With regard to TSS, the requirements have not been met. This indicator can be overstated in lysimeter studies, perhaps due to the unique construction of lysimeters. Most lysimeters are an artificially reconstructed soil profile. The slurries contained in the leachate can be mostly soil, not sewage. In the case of $\mathrm{N}_{\text {tot }}$, it was found that the values obtained exceed the limit values. The limit values for pollution indicators in relation to $\mathrm{N}_{\text {tot }}$ refer to the case when treated wastewater is discharged directly to the lake and their intakes and directly to artificial water reservoirs located in flowing waters. This situation does not occur in the conducted experiment.

\section{CONCLUSION}

Regulations concerning the discharge of sewage to water and soil are limited only to pollution concentration requirements or reducing these concentrations (Rozporządzenie 2014). In the case of soil-plant sewage treatment, a significant reduction in the amount of sewage is a very important element that affects the protection of water quality. Much of the water nutrients contained in the wastewater were used by the plants. It has a significant impact on the load of pollutants introduced into environment. Analysis of the obtained results indicates high efficiency of wastewater treatment in the soil and plant system with the use of energy plants reaching $80-82 \%$ reduction of total suspended solids, $87-92 \%$ of $\mathrm{BOD}_{5}, 87-91 \%$ of COD, reduction of total nitrogen concentration at the level of $46-63 \%$, and total phosphorus $48-65 \%$. The effectiveness of the treatment of sewage in the soil-plant deposits varies depending on the analyzed indicator.

In addition, a significant increase in yields of biomass as a result of irrigated sewage encourages the assumption that, in the case of the treatment of larger amounts of sewage (on larger surfaces), e.g. when treating sewage from sediments, complexes of buildings, etc., the obtained biomass can be used for energy purposes. Several problems were found during the study. The plants used in the experiment are not native plants, which may affect their lower resistance to weather conditions and diseases. Low temperatures in winter, without snow cover, may cause frosting of the till nodes and mother carp. In household (small) wastewater treatment plants, in order to protect plants from catching, you can protect (cover) mother carp and plant propagation nodes in order to protect them from freezing. In addition, the mallow used in the experiment is susceptible to diseases, such as those caused by Sclerotinia sclerotiorum (Lib.) de Bary which in the case of sewage irrigation have good conditions for development.

\section{REFERENCES}

Czyżyk F., 1994. Wpływ wieloletnich nawodnień ściekami na glebę, wody gruntowe $i$ rośliny. Rozprawy Habilitacyjne - Instytut Melioracji i Użytków Zielonych, Wyd. IMUZ, Wrocław.

Czyżyk F., Pulikowski K., Strzelczyk \& Pawęska K., 2012. Efektywność oczyszczania ścieków bytowo-gospodarczych w oczyszczalniach gruntowo-roślinnych i glebowo-roślinnych. Woda - Środowisko - Obszary Wiejskie, 12(4), 97-108.

Eymontt A. \& Gutry P., 2010. Rozwiązania techniczne kanalizacji sanitarnej z zastosowaniem oczyszczalni przydomowych. Problemy Inżynierii Rolniczej, 4, 141-154.

Eymontt A. \& Rogulski B., 2006 Oczyszczalnie przydomowe a zagrożenie środowiska. Problemy Inżynierii Rolniczej, 2, 107-116.

GUS, 2012. Wyniki narodowego spisu powszechnego ludności i mieszkań 2011 r. Główny Urząd Statystyczny, Warszawa, [on-line:] https://stat.gov.pl/cps/rde/xbcr/ gus/lu_nps2011_wyniki_nsp2011_22032012.pdf [access: 30.11.2017].

GUS, 2017. Ochrona środowiska 2017. Główny Urząd Statystyczny, Warszawa.

Gutry P., Zajkowski J. \& Wierzbicki K., 2009. Czy można taniej oczyszczać ścieki na obszarach wiejskich? Wiadomości Melioracyjne i Łąkarskie, 3, 132-135. 
Jucherski A., 2007. Ocena jakości oczyszczania ścieków bytowych w quasi technicznej instalacji zagrodowej typu IBMER na terenach górzystych. Problemy Inżynierii Rolniczej, 2 51-59.

Krzanowski S., Jucherski A. \& Wałęga A., 2005. Wpływ pory roku na niezawodność technologiczną wielostopniowej, gruntowo-roślinnej, przydomowej oczyszczalni ścieków. Infrastruktura i Ekologia Terenów Wiejskich, 1, 37-55.

Miernik W., 2007. Skuteczność oczyszczania ścieków wiejskich w oczyszczalni z reaktorem o działaniu sekwencyjnym. Infrastruktura i Ekologia Terenów Wiejskich, 2, 71-80.

Paluch J., Paruch A. \& Pulikowski K., 2006. Wstępne wyniki badań oczyszczalni zagrodowej typu ORP. Woda - Środowisko - Obszary Wiejskie, 6(1), 297-305.

Pawęska K. \& Kuczewski K., 2016. Changes in increment of trees diameters on plant-soil treatment system after long-term irrigation with domestic sewage. Archives of Environmental Protection, 42, 4, 96-103. DOI: https:// doi.org/10.1515/aep-2016-0046.

Pawęska K. \& Malczewska B., 2009. Sposoby oczyszczania małych ilości ścieków na terenach górskich bez centralnej kanalizacji. Ochrona Srodowiska i Zasobów Naturalnych, 38, 286-297.

Rozporzadzenie Ministra Środowiska $z$ dnia 18 listopada 2014 r. w sprawie warunków, jakie należy spetnić przy wprowadzaniu ścieków do wód lub do ziemi, oraz w sprawie substancji szczególnie szkodliwych dla środowiska wodnego. Dz.U. 2014 poz. 1800.

Soroko M., 2004. Zwiększone usuwanie związków azotu ze ścieków z małych ubojni w oczyszczalniach hydrofitowych. Infrastruktura i Ekologia Terenów Wiejskich, 2, 51-60.

Strzelczyk M., 2011. Wstępne wyniki badań redukcji ładunku zanieczyszczeń w ściekach wiejskich wykorzystywanych do nawadniania roślin energetycznych. Nauka Przyroda Technologie. Uniwersytet Przyrodniczy w Poznaniu, 5, 4, 49.

Strzelczyk M. \& Pulikowski K. 2011. Redukcja stężeń składników biogennych w ściekach wiejskich w środowisku glebowo-roślinnym $\mathrm{z}$ zastosowaniem roślin energetycznych. Zeszyty Problemowe Postępów Nauk Rolniczych PAN, 564, 217-224.

Strzelczyk M., Pulikowski K., Steinhoff-Wrześniewska A. \& Pawęska K., 2012. Ocena skuteczności oczyszczania ścieków wiejskich w środowisku glebowo-roślinnym na podstawie badań lizymetrycznych. Woda - Środowisko Obszary Wiejskie, 12(4), 267-279.

Vymazal J., 2002. The use of sub-surface constructed wetlands for wastewater treatment in the Czech Republic: 10 years experience. Ecological Engineering, 18, 633-646. DOI: https://doi.org/10.1016/S0925-8574(02)00025-3. 